-Journal Publications • Research Consultancy

\title{
AN ASSESSMENT OF THE IMPACT OF THE COVID-19 PANDEMIC ON THE INDIAN ECONOMY
}

\author{
Dr. SANA BEG ${ }^{1} \&$ Mr. SALIK SHUJA ${ }^{2}$ \\ ${ }^{1}$ Assistant Professor, Department of Management, Jamia Hamdard, New Delhi, India \\ ${ }^{2} P G$ Student, Department of Management, Jamia Hamdard, New Delhi, India
}

\begin{abstract}
The Indian economy since last couple of years had faced many disruptions, i.e. demonetisation and GST being the major ones. These disuptions together with global factor had caused a major slowdown in the Indian Economy. India was witnessing a high rate of unemployment and very low aggregate demand. And to make situation worse, the coronavirus struck and it becoming a pandemic affecting every corner of the world. India took a decision of an early and complete lockdown in March to minimise the impact of this pandemic. However, it is difficult to say if the lockdown had any impact on the spread of disease but it did impact the economy is a big way. Few industries are hit more than the others. The way businesses were being done is under revision and the success would be dependent on who is able to adapt to these changes. This paper is an attempt to assess the impact of the Covid-19 pandemic on the Indian Economy.

KEYWORDS: Coronavirus outbreak, Indian Economy, Economic slowdown \& Covid-19 Pandemic
\end{abstract}

Received: Aug 05, 2020; Accepted: Aug 25, 2020; Published: Nov 06, 2020; Paper Id.: IJMPERDAUG202034

\section{INTRODUCTION}

The Coronavirus outbreak, which originated in China and was declared a pandemic on 12 March 2020 by World Health Organosation, is affecting 210 countries and territories around the world. The global economy is going through a very challenging time that was already facing the greatest economic downturn in the aftermath of global financial crisis.

The Managing Director of International Monetary Fund, Kristalina Georgieva said that the year 2020 could see the worst global economic fallout since the Great Depression of the 1930ss. It is predicted that many countres are likely to experience negative GDP growth.

Meanwhile in India COVID-19 cases surge to 5,66,840 ${ }^{1}$ and death count to $17,410^{2}$ as of June 30 . Countries, including India have been put under stringent social intervention which are absolutely necessary at the time also have huge economic implications. . It might probably be the deepest recession that we have had since World War II. IMF in April World Economic Outlook ${ }^{3}$ slashed its projection by 6.3 percentage points from its January forecast of $3.3 \%$ growth to $\mathbf{- 3 \%}$ leaving world economy in fear and uncertainty as recession of 2009 saw

\footnotetext{
${ }^{1}$ https://www.worldometers.info/coronavirus/country/india

${ }^{2}$ https://www.worldometers.info/coronavirus/country/india
}

${ }^{3}$ https://www.imf.org/en/Publications/WEO/Issues/2020/04/14/weo-april-2020 
world output contract by a mere $0.1 \%$ But this one is different, because this recession is artificial. The government restricting people not to go to work to slow down the spread of virus is resulting in a recession like situation.

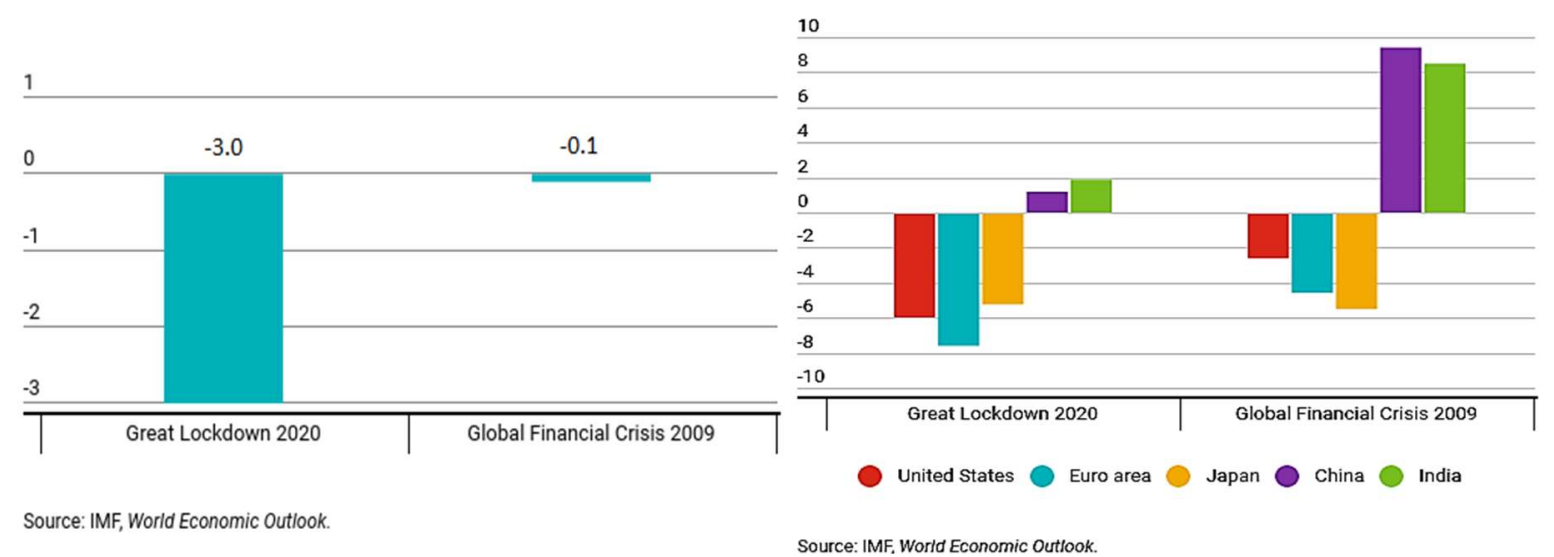

Figure 1

Government of India making its boldest move in war against COVID-19 ordered a nationwide lockdown on $24^{\text {th }}$ March. Shutting down an entire nation of 36 states and territories spanning 3.2 million sq. km for 3 weeks, causing cities to be shut down, production to be stalled and job losses on anvil, which will soon bring the Indian economy on the verge of economic catastrophe. Indian economy had been struggling from the past economic disruptions like demonetisation and GST. Meanwhile IMF also cuts its projection for growth in the fiscal year that started from April 1 from January 5.8\% to $1.9 \%$. Moody's too slashed Indian GDP of 2020 to $2.5 \%$ and further cut to $0.2 \%{ }^{4}$. The GDP growth in the present year ranges from +1.2 percent to -11 percent growth. As $U N$ forecasted of +1.2 percent growth ${ }^{5}$, Bloomberg forecast a decline of $(-0.4)$ percent, Fitch- S\&P AND ICRA foretell of (-5) percent decline and former financial secretary Subhash Chandra Garg stated that there could be $10 \%$ decline of GDP or 20 lakhs crore of income 6 .

\section{An Assessment of the Short-term Impact of COVID'19 pandemic on the Indian Economy}

If disease hit the world, it hit the poor people worst. As the lockdown was announced millions of people were stuck, far away from their homes. It was particularly hard for the people who are at the bottom of the pyramid and have almost no savings, i.e. the migrants and the daily-wage workers struggling for food and to feed their families with their empty pockets.

It is the very reason that thousands of Indians decided and embarked on foot journeys of hundreds of miles slinging bags over their shoulders and carrying their children on their backs, exposing themselves to disease by joining thousands on roads and bus terminals. This mass migration horrified Indian and exposed the problems because of unplanned lockdown. This mass exodus of labourers to their native villages from the cities of India, is now leading to another problem - acute shortage of labour in factories post lockdown.

The timing of COVID-19 and subsequent lockdown coincided with critical period of agriculture sector. March-May is the harvest season for the Rabi crop such as wheat and maize. Even potatoes and onion are also harvested during this period. On grounds and fear of being infected, impacted the sector on labor shortage. Due to disruption in logistics, the

\footnotetext{
${ }^{4}$ https://economictimes.indiatimes.com/news/economy/indicators/moodys-slashes-india-growth-forecast-to-0-2-per-cent-for-2020/

${ }^{5}$ https://www.business-standard.com/article/economy-policy/india-to-grow-at-1-2-in-cy20-global-gdp-to-shrink-by-3-2-says-un-120051400068_1.html ${ }^{6} \mathrm{https} / /$ economictimes.indiatimes.com/news/economy/indicators/indian-economy-to-contract-10-this-fiscal-subhash-chandragarg/articleshow/76163553.cms
} 
farmers who had already harvested their crop were stuck with large amount of produce especially fruits, vegetables, flowers and even poultry. And due to this farm pricing were collapsing pushing farmer into destitution. Having Kharif season around the corner further escalating the problem for farmers. However, to tackle this problem to some extent, the government has raised the Minimum support price (MSP) on 14 Kharif crops for the 2020-21 season, farmer will get Rs 50-755 per quintal extra minimum price which give them return of $50-83 \%$ on cost.

Tens of thousands are finding themselves out of job even in the organised sector. Confining millions to their homes to contain covid-19 spread will have direct bearing on economy and consequently increase unemployment. According to the $\mathrm{CIME}^{7}$, unemployment rate during March 30 - April 5 rose to $23.4 \%$ and the labor participation rate fell to $36 \%$. According to the CII CEOs Snap Poll ${ }^{8}$ majority of the firms expect revenues to fall more than 10 per cent and profits to decline by 5 percent in the current quarter. $52 \%$ of participating CEOs foresee job losses in their respective sectors. It is not just staff working at shops and big stores losing jobs but also temporary staff employed in small shops and with roadside vendors is equally at risk as falling business forcing their employer to retrench. It also includes sharp drop in income of thousands of rickshaw-pullers and taxi drivers.
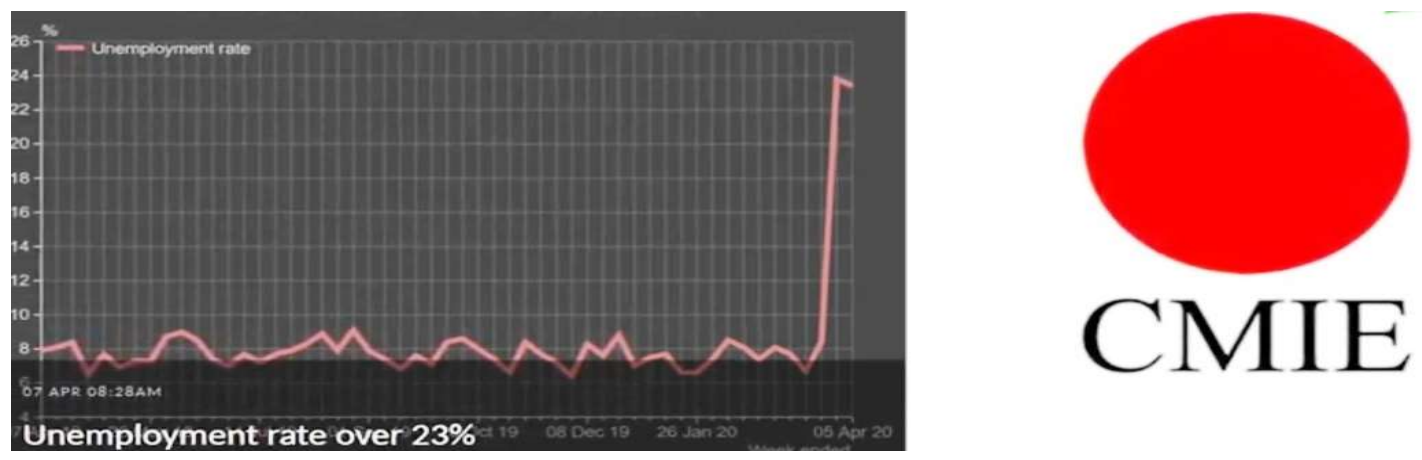

However bringing certain amount of relief, the government launched a PM SVANidhi (PM Street vendor's AtmaNirbhar Nidhi), which provide working capital loan to up to Rs 10,000 , repaid in monthly installment over a year without a penal provision, this will help 5 million people, including vendors and hawkers to restart their business.

CRISIL expects cement industry overall in precarious position as timing of COVID 19 being concurrent with the peak demand season of January to June, as lockdown will have serious impact on margin and revenue during the most profitable quarters. All India Motor transport Congress (AIMTC),"even if the lockdown is lifted is lifted it will take further to be at least 3 months for truckers to limp to some normal case".

The aviation industry, travel agencies and company organizing travel tours are taking a hit after passenger traffic dropped significantly. The Indian aviation industry, who supports 8 million jobs and contributed to $\$ 72$ billion to GDP, have been pushed into the prolonged period of turbulence, when Indian government puts travel restrictions to limit the spread of the virus. Various airlines have curtailed or completely suspended international services, cutting salaries and asking employee to go on unpaid leave. Indigo announced pay cut for up to $25 \%{ }^{9}$ including for $\mathrm{CEO}$ and whereas GoAir terminated contracts

\footnotetext{
${ }^{7}$ https://www.cmie.com/kommon/bin/sr.php?kall=warticle \&dt=2020-04-07\%2008:26:04\&msec $=770$

${ }^{8} \mathrm{https} / / / \mathrm{www}$. businesstoday.in/current/economy-politics/coronavirus-impact-ceos-fear-job-losses-fall-in-revenue-profitreveals-cii-snap-poll/story/400223.html

${ }^{9}$ https://www.bloombergquint.com/business/indigo-announces-pay-cut-for-senior-employees-ceo-takes-25-cut
} 
of expat pilots and laid off several workers.Indian lenders have asked central bank to allow them to restructure loan worth about three lakhcrore given to hospitality, aviation and commercial property companies without downgrading their assets on their books. Banks state their concerns that NPA on their balancesheet will surge, repayment moratorium will not be enough and it may take few quarters to have cashflow sufficient to meet repayment obligation. According to the CRISIL, NPAs are set to swell to nearly $11.5 \%$ of total credit in banking system from $9 \%$ now.

Travel and tourism sector which provide 42.67 million jobs and nearly $8 \%$ of country's total employment, is badly hit.And ithas become more worse as aviation and travel agencies have lost the major holiday time of summers, a holiday season which is peak time for international and domestic flights. As families tends to travel for three month starting from March. According to the CAPA India, Indian aviation sector was predicted to suffer a wobbling USD 3.3-3.6 billion ${ }^{10}$ losses in the first quarter of next financial year because of non resumption of flight flight services till June-end. It also warned that many airlines could face bankruptcy. In the near future as well, demand is expected to remain sluggish, because people are expected to avoid or postpone non-essential travel and focus on money saving.

The Indian rupee had slipped to a record low of 76.90 against US Dollar - report by liveMint ${ }^{11}$. Though currently hovering at around 75, but according to the experts if coronavirus cases continue to increase on global and local front rupee could move further towards 77 and 78 level. A big sell-off in the domestic stock market and further sell off the equities is a major threat for rupee growth forward. However "Indian rupee might appreciate a bit in short term on softening of crude oil prices and rise in risk appetite in the domestic market as talks of the partial lifting of lockdown gain currency"- Sharekhan, Broking firm. Also US Dollar continue to shine against other basket of currencies as investors fled with their riskier assets to the world's most liquid currency.

Indian automaker may experience an aggregate drop of $20 \%$ or Rs 75,000 crore or ( $\$ 10$ billion) in revenue. According to CRISIL ${ }^{12}$, Capacity utilisation by passenger car maker may descend to $39 \%$, to $45 \%$ for commercial vehicle and to $50 \%$ for two-wheeler. However, the silver lining is there might be an increased demand for the entry level car in the short run due to coronavirus as people may prefer their own vehicle over cab to avoid the spread of virus. Similar will be the case with two-wheeler and other personal mobile option- top personnel of Maruti Suzuki told business standard

With 80\% COVID-19 cases in India remain asymptomatic(which don't show any symptoms at all and can become silent spreader) according to the Indian Council Of Medical Research was the reason of further extension of lockdown beyond 21 days to tackle the present health crisis with extremely limited resources and this further devastated the economy.

Over and above of that, the inconsistent regulation and lack of collaboration among various levels of government municipality as well as central and state government with their flip-flop on their regulations aggravated the problems for the businesses, which have also lately being suffering from shortage of labour.

\section{An Assessment of the long-termImpact of COVID'19 pandemic on the Indian economy}

In the long run a lot will depend upon the transmission of virus, duration and nature of restrictions and how the governments

\footnotetext{
${ }^{10} \mathrm{https}: / /$ economictimes.indiatimes.com/industry/transportation/airlines-/-aviation/indian-aviation-sector-may-incur-3-3-36-billion-loss-in-june-quarter-capa-india/articleshow $/ 74813509 . \mathrm{cms}$ ?from $=\mathrm{mdr}$

${ }^{11} \mathrm{https}: / /$ www.livemint.com/news/india/rupee-dollar-exchange-rate-today-inr-slips-to-record-low-near-77-per-usd$11587528914686 . h$ html

${ }^{12} \mathrm{https}$ ://economictimes.indiatimes.com/industry/auto/auto-news/auto-industry-may-fall-out-of-gear-thisfiscal/articleshow/76206258.cms?from $=\mathrm{mdr}$
} 
will response to it. The world's largest lockdown of India is expected to have costed the Indian economy almost over 35000 crore on a daily basis-according to Acuite ratings $\&$ research ${ }^{13}$.

Even after the lockdown is lifted, millions feel the pain of unemployment or salary cuts in India. This may take years to come back to normal. There could be job losses of millions in across travel and tourism sector according to the Travel Agents Federation of India(TAFI). "The revenue loss ofhospitality sector is pegged at $\$ 14.67^{14}$ billion over the next one year in the worst case scenario.In the long run new travel trend and consumer preferences will give much needed boost to travel industry. Destination which are within the driving distance of major urban centres are likely to see the boost. Increase in domestic travelling giving boost to " Dekho Apna Desh".

Consumer durables, automotive industry, capital goods and MSMEs sectors will be among the worst affected. The IT sector which employ among 4 million engineers is likely to witness around $5 \%{ }^{15}$ job losses,says TV Mohandas PAI, venture capitalist and former HR director, Infosys.

Overcoming the problems of Manufacturing sector and supply chain depends upon how soon the situation normalises and the various state governments lift all the restrictions. The Partial resumption of construction activities as 70\% of highway project are approved by Ministry of Home Affairs(MHA), should ease out the pain of cement industries. However production and execution will continue to affected due to mass migration of labourers back towards their homes and villages. The FMCG sector is expecting a V-shaped recovery in essential goods and U-shaped recovery in the luxurious items.

The Pharma-sector is expected to be better off in the long run as demand of pharma products will increase in future.India imports $\$ 3.5$ billion annually API (Active pharmaceutical ingredient) which are key ingredient to make medicine, and 70\% comes from China. Its supply chain disruption, because of political reasons or otherwise, will affect the pharma industry in a big way. However India plans to draw foreign major to ramp up for providing APIs, as this dependence on import could have strategic dimension and undermine public health.

With only $10 \%$ of Indians of over 500 million workforce working in formal sector, the rest $90 \%$ worforce in informal sector and are under constant threat of hunger and poverty. People will not buy or take work from the daily wage earners, rehriwallas, rickshaw-pullers, local cloth shops, tailors, roadside vegetable and fruit sellers, local ration shops, plumbers, carpenters and local electricians, and instead pefer to buy groceries online, online retailer or professional online service providers because of fear of being exposed to infection. "Customers will be reluctant to go to places where there isn't enough social distancing and hygiene standards are not perceivable available”, Kumar Rajgopalan ,CEO, Retailers Association Of India.

There could be change in investment pattern as according to the economic times and institutional investors, value investing will likely to make a comeback. With earning growth lagging, value investment has not worked for past 4-5 years, is set to comeback after coronavirus crash. Investors could be targeting mid to large size business with robust fundamentals and avoid valuing the business on traditional metrics to as certain margin of safety.

Rupee may depreciate against dollar. It is already at an all time low. A strong dollar may result in continued FII

\footnotetext{
${ }^{13} \mathrm{https} / /$ economictimes.indiatimes.com/news/economy/finance/worlds-biggest-lockdown-may-have-cost-rs-7-8-lakh-crore-to-indianeconomy/articleshow/75123004.cms? from $=\mathrm{mdr}$

${ }^{14}$ https://www.thehindubusinessline.com/economy/hospitality-sector-stares-at-6-14-b-losses-in-fy21/article31461325.ece

${ }^{15} \mathrm{https}$ //www.deccanherald.com/business/business-news/coronavirus-outbreak-job-loss-pay-cut-on-cards-for-millions-inindia-821019.html
} 
outflow from local shares. FPIs have withdrawn over Rs15000 crore in April alone, according to the financial express ${ }^{16}$.

According to a report of World bank- COVID-19 Crisis through a migration lens, remittances to India will fall $23 \%{ }^{17}$ due to COVID-19.The fall is likely be of 19 billion dollar from 83 billion dollar of last year to 64 billion dollar. Remittances provide economic lifeline to poor households in country. However amount of remittances received by India is only 2.3\% of GDP(WB estimates, WB development indicators,IMF balance of payment statistics), it will not effect in short run but can have serious cascading effect on Indian economy in the long run as World Bank expects it may continue upto FY22 also. Decrease in remittances lower the purchasing power of Indians which will subdue demand, that will lead to lower production and results in loss of jobs.

The government's economic packages (1.7lakh crore and subsequently the 20 lakh crore) and the measure taken by RBI (three month moratorium scheme and one lakh crore funding targeted to NBFCs NHB and Sidbi) to address liquidity crunch will ease the pain it, but can only lessen the negative impact we may see in the next couple of years. We are in serious need of structural reforms - especially in agriculture sector.

With Brent Crude falling to $\$ 20$ per barrel, India missed the opportunity of taking advantage of the fall in demand due to lockdown and lower demand as every dip of $\$ 10$ in oil price, reduces the import bill by $\$ 15$ billion. Another problem with India is the limitation to stock up cheap crude oil for future.Although India being third largest consumer in the world, the whole SPR ${ }^{18}$ storage capacity comes to just 39MB as compared to528MB of Japan and $550 \mathrm{MB}$ of China.

The COVID-19 pandemic has intensified the problem of global supply chain. In the aftermath of the pandemic, advance countries may think of producing in their own countries rather than importing. They will now invest more in artificial intelligence and robotics to actively face any future uncertainity and lower the manpower from developing countries. This will pose serious threat to India in future. As the pandemic wreaked the havoc in western economies, there may be rise in xenophobia and discrimination against migrant workers, to provide the left out jobs to their citizens.

Agriculture could be at the forefront in reviving economy. After recording highest rainfall in last 25 years in 2019, India is all set to witness good monsoon season again this year. IMD predicts a normal monsoon for 2020 and also expects $100 \%{ }^{19}$ long period average (LPA is the benchmark against which IMD measure monsoon). South-western monsoon which irrigates over half India's cropland and sustain the livelihood of over $58 \%$ of population, could lift up the plight of Indian farmers. Economists are suggesting that robust agri-economy can act as starting point in the long run.

\section{CONCLUSIONS}

The economic crisis induced by the COVID-19 pandemic could be long, deep, and pervasive. This pandemic has proven to be the ultimate test for governance system, overwhelmed health care system and could destroy the economy. The Indian healthcare system is woefully inadequate and received just over 1\% of GDP. The economy is already in fragile condition

\footnotetext{
${ }^{16} \mathrm{https}: / \mathrm{www}$.financialexpress.com/economy/flight-of-foreign-investors-continues-in-april-fy21-starts-on-a-bad-note-asfpis-pull-out-more-investment/1945187/

${ }^{17} \mathrm{https}: / / \mathrm{www}$.thehindu.com/business/Economy/coronavirus-2020-global-remittances-to-witness-sharpest-fall-in-recenttimes-says-world-bank/article31407369.ece

${ }^{18} \mathrm{https}: / / \mathrm{m}$. economictimes.com/industry/energy/oil-gas/indias-oil-import-bill-may-halve-if-current-crude-priceholds/articleshow/74548791.cms, SPR- Strategic petroleum reserve

${ }^{19} \mathrm{https}: / / \mathrm{www} . c n b c t v 18 . c 0 \mathrm{~m} /$ economy/imd-predicts-normal-monsoon-this-year-expects-100-of-long-period-average-

5693611.htm\#: :text=The\%20India\%20Meteorological\%20Department\%20(IMD, which\%20the\%20IMD\%20measures\%2 0monsoon.
} 
The government are at a critical juncture where either they can support healthcare system and save people lives from the deadly coronavirus disease or protect the already fractured economy, according to Dr. Raghuram Rajan - the man who predicted the financial crisis.

The post-Corona world would be different in many ways. New business models would eveolve, new skills and knowledge would develop and on the other hand unfortunately, many job losses would also be witnessed. The pandemic has certainly changed the way we look at health care and think about reforming it and people will agitate for good benefits. Surely we have to revisit the way we live in and utilizing resources prudently. Obviously with the necessary protocols and maintaining standards of safety and hygiene, the world may never be the same again.

Covid-19 has posed a big challenge to the Indian government that was facing a big slowdown. So much so that Moody's slashed India's sovereign rating by notch to Baa3 to Baa $2^{20}$ - with negative outlook, have stated exclusively that latest downgrade is not because of COVID 19 but due to weak implementation of reform measures. Declining growth rate of 2019-20 due to structural problems- COVID -19 pandemic only brought this to fore.

Lockdown gave the government adequate preparation time to organize an orderly and safe restart of the economy. However, they are still lots of ifs and buts and the future is more uncertain than it has ever been. The Government of India has declared many packages to keep the economy on track. Right implementaion of these plans and policies may save India from falling into depression.

\section{REFERENCES}

1. www.worldometers.info/coronavirus/country/india

2. www.imf.org

3. www.economictimes.indiatimes.com

4. www.business-standard.com

5. www.cmie.com

6. www.businesstoday.in

7. www.bloombergquint.com

8. www.livemint.com

9. www.thehindubusinessline.com

10. www.deccanherald.com

11. www.financialexpress.com

12. www.thehindu.com

13. www.cnbctv18.com

14. www.yourstory.com

\footnotetext{
${ }^{20} \mathrm{https} / / /$ yourstory.com/2020/06/moodys-downgrades-india-rating-to-baa3
} 

